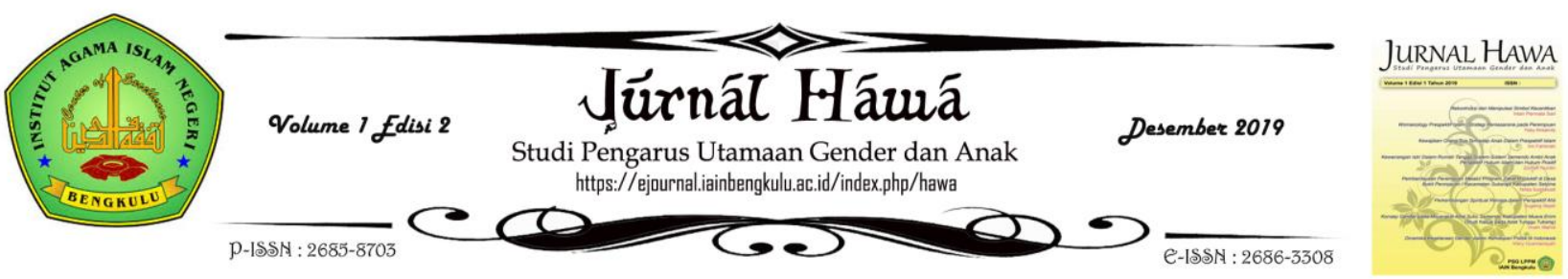

\title{
Pendekatan Feminis dalam Studi Islam Kontemporer
}

\author{
Ismail \\ ismailmunir1972@gmail.com \\ IAIN Bengkulu
}

\section{Info Artikel}

\section{Diterima: Oktober \\ 2019}

Disetujui: Oktober

2019

Dipublikasikan:

Desember 2019

\section{Keyword}

Keywords: feminist, gender, al-Qur'an, Hadith.

\section{Abstract}

Feminist Approaches in Contemporary Islamic Studies. Discussing issues between men and women is always hotly discussed regarding the basic rights that are ignored, marginalized or oppressed by the prevailing system in society. The phenomenon of gender injustice has manifested itself in various forms such as the marginalization of women in the economic sector, the subordination of political decisions, the formation of stereotypes or negative labeling, violence against women, unfair distribution of workloads, and the lack of ideological socialization of the value of gender roles. Looking at the above discussion, research needs to be conducted with the aim that feminists are moved to spark Islamic tools with a perspective of gender justice to deconstruct religious texts in an effort to realize gender equality and equality in Islam. Descriptive method using a feminist approach in studying Islam is intended as an effort to give birth to new readings of religious understanding in the contemporary context which berorietasi on the liberation of women from the shackles of trapping tradition. Thus, the study of equality models in the feminist approach was initiated by figures such as; Qosim Amin, Aminah Wadud Muhsin, Fatima Mernisi, Asghar Ali Engineer and Nasaruddin Umar produced a fresh understanding of religion, where humans as legal subjects were placed in positions that did not subordinate, discriminate or marginalize one for another on any basis, either ethnicity, gender, religion and race. Islam actually legitimizes the existence of women. With the hope, Islamic feminists must re-criticize the interpretation of religious texts (verses of al-Qur'an and al-Hadith) which have gender bias so that there is no wrong understanding.

\section{Kata Kunci}

Kata Kunci: feminis, gender, al-Qur'an, Hadis.

\section{Abstrak}

Pendekatan Feminis dalam Studi Islam Kontemporer. Mendiskusikan persoalan antara laki-laki dan perempuan selalu hangat diperbincangkan menyangkut hak-hak dasar yang terabaikan, terpinggirkan atau tertindas oleh sistem yang berlaku di masyarakat. Fenomena ketidakadilan gender itu telah termanifestasi dalam berbagai bentuk seperti marginalisasi perempuan di sektor ekonomi, subordinasi keputusan politik, pembentukan stereotype atau pelabelan negatif, kekerasan terhadap perempuan, distribusi beban kerja yang tidak adil, serta minimnya sosialisasi ideologi nilai peran gender. Melihat persoalam di atas, perlu dilakukan penelitian dengan tujuan agar kaum feminis tergugah hatinya untuk mencetuskan piranti keislaman berperspektif keadilan gender untuk mendekontruksi teks-teks keagamaan dalam usaha mewujudkan keadilan dan kesetaraan gender dalam Islam. Metode deskriptif dengan menggunakan pendekatan feminis dalam mengkaji Islam ini dimaksudkan sebagai upaya melahirkan bacaan baru terhadap pemahaman keagamaan dalam kontek kontemporer yang berorietasi pada pembebasan perempuan dari belenggu-belenggu tradisi yang menjerat. Dengan demikan, kajian tentang model-model kesetaraan dalam pendekatan feminis yang digagas oleh para tokoh seperti; Qosim Amin, Aminah Wadud Muhsin, Fatima Mernisi, Asghar Ali Engineer dan Nasaruddin Umar ini menghasilkan pemahaman yang fresh tentang agama, di mana manusia sebagai subjek hukum ditempatkan pada posisi yang tidak saling mensubordinasi, mendiskriminasi atau memarginalkan satu atas yang lain atas dasar apapun, baik etnisitas, gender, agama, maupun ras. Islam justru melegitimasi eksistensi keberadaan wanita. Dengan harapan, kaum feminis Islam harus mengkritisi kembali penafsiran terhadap teks-teks keagamaan (ayat al-Qur'an dan al-Hadis) yang memiliki bias gender sehingga tidak terjadi pemahaman yang salah. 


\section{Pendahuluan}

Mendiskusikan

kaum perempuan dan kedudukannya dalam kehidupan sosial tentu menarik. Apalagi dalam masyarakat yang bersifat patrilineal. Tanpa menggunakan gender sebagai pisau analisa terhadap realita, tidak akan pernah kita dapatkan kejanggalan. Semua proses kehidupan berjalan normal sebagaimana lazimnya. Sehingga, tanpa disadari, kita sendiri terjerumus dalam praktek misogini, sebuah idiom modern yang berarti tindakan penindasan terhadap kaum perempuan, baik secara langsung maupun tidak langsung dan baik berlangsung dengan kasar maupun halus. Memang, tidak selamanya kekerasan dan ketidakadilan gender dilakukan oleh lelaki terhadap perempuan, melainkan bisa juga terjadi antara perempuan terhadap lelaki. Namun karena relasi kekuasaan gender yang berlangsung di masyarakat, umumnya yang menjadi korban kekerasan gender adalah kaum perempuan. Sayangnya, ketidakadilan tersebut belum bisa dirasakan oleh semua pihak, termasuk oleh sebagian besar kaum perempuan yang menjadi korbannya. Menurut Mansour Fakih, hal itu disebabkan karena mereka belum memiliki kesadaran dan sensitivitas gender. ${ }^{1}$

Ketika alat analisa gender dalam ilmu-ilmu sosial ditemukan, barulah terasa ada yang tidak beres dalam keseharian hidup kita. Satu contoh, hampir semua ulama Fiqh pada periode awal telah lengah dalam menafsirkan ayatayat gender dalam al-Qur'an, sehingga mereka memahaminya secara literal. Akibatnya, tidak heran kalau hukum Islam banyak menghadapi serangan gencar di abad modern, dengan tuduhan telah menindas kaum perempuan dan menjadikannya sebagai anggota masyarakat kelas dua. Di lain pihak, kita sendiri cenderung menganggap benar atau paling tidak menganggap biasa praktek misogini yang terjadi, seperti justifikasi makna literal ayat al Qur'an al-rijâlqawwâmûn 'alâ al-nis $\hat{a}^{2}$, dengan alasan bahwa prosentase akal dalam diri perempuan hanya $1 \%$, sedangkan 99\% yang lain dikuasai oleh emosi. Jadi, sangatlah logis kalau

\footnotetext{
${ }^{1}$ Mansour Fakih, Analisis Gender \&Transformasi Sosial, (Yogyakarta: PustakaPelajar, 2012), hlm. 135.

${ }^{2}$ QS. An-Nisa: 4 ; 34.
} 
mereka tidak dibebani dan tidak boleh diberi tanggungjawab di luar batas kemampuan kodrati tersebut. Sampai kaum perempuan sendiri seringkali membenarkan pandangan seperti ini. Bahkan mereka menjadikan ayat-ayat tersebut untuk menjustifikasikan

ketidakmampuan diri dan berperilaku bak inderella yang hanya bisa dilindungi, ditolong, dijaga, dan diperhatikan.

Penelitian literasi ini berusaha mendeskripsikan pendekatan feminis terhadap studi agama dalam bacaan kontemporer. Model bacaan ini tidak lain merupakan suatu transformasi kritis dari perspektif teoritis yang ada dengan menggunakan gender sebagai kategori analisis utamanya. Para feminis religious seperti pernah lakukan penelitian oleh Anne Carr, disatukan oleh suatu keyakinan bahwa feminis dan agama keduanya sangat signifikan bagi kehidupan kaum perempuan dalam era kontemporer. $^{3} \quad$ Sebagaimana

\footnotetext{
${ }^{3}$ Anne Carr,Tranforming Grace: Christian Tradition and Women's Experience (San Francisco: Harper \& Row, 1988), hlm. 95. Dalam Peter Connolly (ed.), Aneka PendekatanStudi Agama, (Yogyakarta: LKiS, Cet,III 2011). Sue Morgan menulis dalam "Pendekatan Feminis", hlm. 63.
}

agama, feminism memberikan perhatian pada makna identitas dan totalitas manusia pada tingkat yang paling dalam, didasarkan pada banyak pandangan interdisipliner baik dari antropolog, teolog, sosiolog, dan filosof. Tujuan utama dari tugas feminis adalah mengidentifikasi sejauh mana terdapat persesuaian antara pandangan feminis dan pandangan keagamaan terhadap kedirian, dan bagaimana menjalin interaksi yang paling menguntungkan antara satu dengan yang lain. Dengan harapan, sudah menjadi rahasia umum, salah satu dasar pemikiran feminism adalah pandangan bahwa peran dan tanggungjawab yang berbeda antara laki-laki dan perempuan didasarkan atas nama budaya yang mengitarinya.

\section{Istilah dan Karakteristik Dasar Pendekatan Feminis \\ Dari segi bahasa} (etimologi) feminis berasal dari kata femme (woman, perempuan (tunggal) yang berjuang untuk memperjuangkan hak-hak kaum perempuan sebagai kelas sosial. Istilah ini perlu dibedakan antara male dan female (sebagai aspek perbedaan biologis), sebagai 
hakikat alamiah, masculine dan feminine (sebagai aspek perbedaan psikologis cultural). Dengan kata lain, male-female mengacu pada seks, sedangkan masculine-feminine mengacu pada jenis kelamin atau gender, sebagai he dan she. Jadi tujuan feminis adalah keseimbangan, interelasi gender. Dalam arti luas, feminis adalah gerakan kaum wanita untuk menolak segala sesuatu yang dimarginalisasikan, disubordinasikan, dan direndahkan oleh kebudayaan dominan, baik dalam politik dan ekonomi maupun kehidupan sosial pada umumnya. Dari ungkapkan teori di atas, dapat ditarik kesimpulan bahwa gerakan feminism dilakukan untuk mencari keseimbangan gender (rasisme, stereotyping, seksisme, penindasan

perempuan, dan phalogosentrisme).

$$
\text { Sejak tahun }
$$

pertumbuhan dan diversifikasi pendekatan feminis ditandai dengan upaya untuk menciptakan materi baru dan digunakannya paradigma kesarjanaan keagamaan yang baru pula, dengan memperbaiki model androsentris sebelumnya dengan lebih cenderung mengistimewakan pengalaman perempuan. Beragam tanggapan bermunculan. Kaum feminis secara sistematis mengolah kembali konsep-konsep utama seluruh tradisi keagamaan. Misalnya karya Judith Plaskow Standing Again at Sinai: Judaism From A Feminist-Perspective (1990), dan karya Rita Gross Buddhism after Patriarch: A Feminist History, Analysis ang Reconstruction of Buddhism (1993), merupakan model terkini dari upaya bacaan kontemporer terhadap ajaran agama. Begitu pula Mary Gery yang melakukan pembacaan ulang terhadap doktrin penebusan, atau feminis Plaslow yang melakukan pembacaan ulang terhadap doktrin dosa. ${ }^{4}$ Dalam bagian ini memaparkan beberapa karakteristik pendekatan feminism terhadap agama karena perbedaan metodologi sebagai rekonstuksi keagamaan feminis yang paling mendasar dan representatif.

Bagi kaum feminis religious upaya menemukan jalan dalam mengimajinasikan Tuhan yang

${ }^{4}$ Mary Gery, Redeeming the Dreem: Feminism, Redemption and Christian Tradition. SPCK, 1989 dan Judith Plaskow, Sex, Sin, and Grace: Women's Experience and the Theologies of Reinhold Niebuhr and Paul Tillich. (Washington: University Press of America, 1980). Dalam Sue Morgan, Pendekatan Feminis, Peter Connolly (ed.), Aneka Pendekatan Studi Agama, (Yogyakarta: LKis, 2011), hlm. 77. 
terkait dan mendukung concern spiritual perempuan merupakan hal yang sangat penting dilakukan. Penelitian yang dilakukan oleh Daly tentang korelasi antara simbolisme keagamaan maskulin secara ekslusif dengan kekuatan lakilaki temporal secara serius diambil oleh kelompok feminis reformis yang melakukan penelitian dengan pemahaman ganda terhadap imagedei yakni adanya kemampuan yang sama antara laki-laki dan perempuan dalam menggambarkan image tentang Tuhan. Menurut Morgan kaum feminis religious berupaya menyesuaikan simbol-simbol Tuhan yang ada dengan mengusulkan rangkaian imageimage yang beragam dan inklusif. Yang mana para sarjana menggunakan sumber-sumber yang bersifat lintas budaya, trans historis yang diambil dari agamaagama kuno, sejarah Yahudi, teks Kristiani, dan agama-agama Timur. ${ }^{5}$ Dalam kaitan ini kaum feminis menggunakan pendekatan pertama, melakukan revisi tekstual secara detail untuk

${ }^{5}$ Lihat Rita Gross, Hindu Female Deities as a resource for the contemporary rediscovery of the goddess, Journal of American Academy of Religion, 1974, hlm. 269-291. Dalam Sue Morgan, Pendekatan Feminis, hlm. 78. menemukan kembali dan memperkuat suara perempuan dalam Injil. Upaya pembacaan ulang terhadap kejadian 2 dan 3 ini, misalnya dilakukan oleh Phyllis Trible menyatakan bahwa laki-laki dan perempuan merupakan mahluk Tuhan yang diciptakan bersama-sama. ${ }^{6}$ Pendekatan kedua, mengacu pada tradisi Kenabian Yesus dalam Injil. Kaum feminis menyatakan hal itu sebagai bukti kemampuan Injil memunculkan perspektif kritisisme diri terhadap patriarki dengan bersumber pada Injil sendiri. Sebagai visi keadilan sosial scriptural yang membebaskan, tradisi kenabian dikaitkan dengan konflik feminis kontemporer masing-masing menjadikan budaya yang melingkupi untuk mengambil keputusan dan menuntut perubahan. ${ }^{7}$

${ }^{6}$ Phyllis Trible, Eve and Adam: Genesis 2-3 reread, dalam Christ dan Plaskow, Womanspirit Rising, hlm. 74-83, dan Judith Plaskow, The Coming of Lilith, hlm. 198-209. Dalam Morgan, ibid, hlm.81.

${ }^{7}$ Ungkapan di atas mengutip pendapat Rosemary Radford Ruether diakui sebagai tokoh utama pendekatan Bibelfeminis. Lihat artikelnya, "Feminism and Patriarchal religion: principles of ideological critique of Bible" Journal for the Study of the Old Testament, 22, 1982, hlm. 54-66. Dan "Feminist Interpretation: A method of correlation" dalam Russell, Feminist Interpretation of the Bible, hlm. 111-124. Ibid..,hlm. 82. 
Karakteristik ketiga dalam perspektif feminis adalah penemuan kembali sejarah keagamaan perempuan. Upaya yang dilakukan oleh kaum feminis religious akhir-akhir ini memfokuskan perhatiannya untuk memperbaiki jarak pandang historis tidak hanya ratu yang saleh atau perempuan suci, melainkan buat perempuan awam religious dalam beragam peran spiritual dan konteks historis. Mulai dari peran pejuang perempuan di masa praIslam sampai pada status perempuan sufi abad tengah yang mendiami ribath, mulai dari partisipasi perempuan dalam kehidupan Israel Kuno sampai pada inisiatif ekonomis istri dan ibu dalam agama Yahudi, dari biarawati-biarawati Katolik Inggris sampai pengkhotbahpengkhotbah suci dari perempuan kulit hitam pada abad XIX, feminis telah mulai merekonstruksi warisan spiritual yang memberdayakan bagi perempuan religious kontemporer. ${ }^{8}$

${ }^{8}$ Lihat Nawal el-Sadawi, The Hidden Face of Eva: Women in the Arab World. (Boston: Beacon Press, 1981; Leila Ahmad, Women and Gender in Islam: (New Haven and Landon: Yale University Press, 1982; Bernadette J. Brooten, Women Leaders in the Ancient Synagogue: Incrption Evidence and Background Issue. (Chicago: Scholar
Dalam Islam justru melegitimasi eksistensi keberadaan wanita. Wanita diberikan porsi hak, kewajiban serta hukum yang sama dengan laki-laki. Dalam salah satu ayat, Tuhan menyampaikan pesan bahwa ganjaran kebaikan yang diterima wanita sama persis dengan ganjaran yang laki-laki terima dalam mengamalkan kebaikan. Islam memberkan ruang lingkungan dan sosial yang layak bagi perempuan. Tidak seperti kebudayaan elite Yunani. Yang mengharuskan wanita selalu berada di dalam istana. Islam memberikan ruang bagi wanita untuk keluar dan berinteraksi. Namun dengan beberapa catatan yang memang harus dipertimbangkan demi kemaslahatan bersama. Wanita juga mendapatkan kebebasan untuk ikut andil dalam menjalankan perputaran roda ekonomi. Mereka memiliki hak untuk mengatur perdagangan

Press, 1982); Paula Hyman, "The Jewish Family: looking for a usable past" dalam Susannah Heschel (ed.). On Being A Jewish Feminist: A Reader. (New York: Schocken Books, 1983), hlm. 19-26. Susan O’Brien, “ Terra Incognita: The Nun in nineteenthcentury England", Past and Present 121, 1988, hlm. 110-140; dan William I. Andrews, (ed.). Sisters of the Spirit: Three Black Women's Autobiographies of the Ninteenth Century. (Bloomington: Indiana University Press, 1986).Dalam Ibid.., hlm.84. 
seperti halnya kaum laki-laki. Juga memberikan ruang gerak wanita untuk berpartisipasi dalam ruang publik. Menurut Zakaria al-Anshory dalam karyanya lubbulushul, ia menyinggung ayat arrijalu qawwamuna alannisa'. Bahwa lakilaki lebih kuat dan lebih tangguh dari pada wanita. Ia mengatakan, lafal arrijal dan annisa' dalam ayat di atas sama-sama bersambung dengan alif-lam yang disebut mahiyah jinsiyah. Singkatnya, memang pada hakikatnya lakilaki lebih kuat dari pada wanita, namun itu tidak menutup kemungkinan sebaliknya. Bahwa wanita memiliki kemampuan dan kapabilitas dalam memimpin kaum laki-laki itu mungkin saja. Hanya saja, itu terjadi sebagai sesuatu yang jarang, tidak secara global dan menyeluruh. ${ }^{9}$

\section{Pendekatan Feminisme Dalam Studi Islam}

Nilai-nilai ajaran Islam hadir tidak untuk mengekang dan memenjarakan kebebasan manusia, justru mendorong kaum perempuan untuk ikut berpartisipasi dalam ruang lingkup publik yang lebih luas.

${ }^{9}$ Muhammad Shodiq Masrur, dalam https://www.nu.or.id/post/read/79772/femini sme-dalam-islam, 2017.
Secara teoritis dan praktis harus ada upaya edukasi kepada masyarakat mengenai pentingnya kesetaraan antara laki-laki dan perempuan. Karena itu diperlukan beberepa pendekatan untuk mengkajinya, di antaranya pendekatan feminis. Dalam konteks ini berbagai ragam pemikir feminis Muslim tampil dan berusaha melakukan dekonstruksi terhadap pemahaman keagamaan yang menempatkan perempuan pada posisi yang setara dengan kaum laki-laki.

\section{Feminisme Model Qosim Amin}

Qasim Amin adalah tokoh feminis Muslim lahir di Tarah, Iskandariah (Mesir), Desember 1865. Di antara karya yang banyak menggugah semangat perempuan untuk bangkit adalah Tahrir al-Mar'ah (1900) dan alMar'ah al-Jadidah (1911). Dua karya inilah yang kemudian banyak memberi inspirasi para feminis Muslim untuk memperjuangkan kebebasan perempuan hingga sekarang. ${ }^{10}$ Harun Nasution menyebut

${ }^{10}$ Muhammad Qutub, Qadliyyah Tahrir al-Mar'ah, alih bahsa Tajudin "Setetes Parfum Wanita" (Jakarta: Pustaka Firdaus, 1993). Dalam Sukri, Sri Suhandjati (Ed.). Bias Jender dalam Pemahaman Islam, (Yogyakarta: Gama Media. Cet. I. 2002), hlm. 194-195. 
Qasim Amin sebagai tokoh feminis Muslim yang memunculkan ide tentang emansipasi perempuan. Menurutnya, keterbelakangan umat Islam itu salah satunya disebabkan oleh persepsi dan perlakuan yang salah terhadap perempuan. ${ }^{11}$ Ide ini mendapat respon keras di kalangan ulama Mesir saat itu. Ide emansipasinya bertujuan untuk membebaskan kaum perempuan sehingga mereka memiliki keleluasaan dalam berpikir, berkehendak, dan beraktivitas sebatas yang dibenarkan oleh ajaran Islam dan mampu memelihara standar moral masyarakat. ${ }^{12}$ Karena itulah ia menyarankan adanya perubahan, tanpa perubahan mustahil kemajuan dapat dicapai.

Menurut Qasim Amin, perubahan mendasar yang harus dilakukan adalah pertama, mewujudkan persamaan di hadapan hukum. Syari'ah menempatkan perempuan sederajat dengan laki-laki dalam

\footnotetext{
${ }^{11}$ Harun Nasution, Pembaharuan dalam Islam: Sejarah, Pemikiran, dan Gerakan. (Jakarta: Bulan Bintang, 1991, Cet. VIII), hlm. 79.

${ }^{12}$ Qosim Amin, SejarahPenindasan Perempuan: $\quad$ Menggugat Islam Lakilaki, Menggurat Perempuan Baru.Alih bahasa Syariful Alam dari The New Woman: A Document in the Early Debate of Egyptian Feminism. (Yogyakarta: Ircisod. Cet. I, 2003), hlm. 49.
}

hal tanggung jawabnya di muka bumi dan di kehidupan selanjutnya. Jika perempuan melakukan tindak kriminal, bagaimana pun juga, hukum tidak begitu saja membebaskannya atau merekomendasikan pengurangan hukuman padanya. Qasim meyakini, tidaklah masuk akal menganggap perempuan memiliki rasionalitas yang sempurna, bebas, dan berhak mendapat hukuman jika ia melakukan pembunuhan, sementara di saat yang sama tidak ada tanggapan apa pun atas perempuan ketika kebebasannya dirampas. ${ }^{13} \quad$ Pengalaman mengindikasikan bahwa kebebasan perempuan bisa menambah pengertian akan tanggungjawab dan kehormatan dirinya, dan mendorong orang untuk menghormatinya. Untuk memperkuat analisisnya, ia menyajikan data statistic bahwa kaum perempuan di Barat (Jerman, Belgia, Perancis, dan Belanda) banyak memperdaya suami mereka. ${ }^{14}$

Kedua, menganjurkan kebebasan bagi perempuan. Karenanya, Qasim mengecam keras tradisi pemingitan

\footnotetext{
${ }^{13}$ Qosim, Ibid..,hlm. 65.

${ }^{14}$ Qosim, Ibid..,hlm. 66.
} 
terhadap perempuan pada waktu itu. Ketiga, Kaum perempuan harus mendapatkan pendidikan yang memadai. Ia kurang setuju jika perempuan diberikan pendidikan yang khusus yang berbeda dengan pendidikan yang diberikan kepada laki-laki. Bahkan ia menegaskan separo dari penduduk dunia adalah kaum perempuan. Karena itu, membiarkan mereka dalam kebodohan berarti membiarkan potensi separo bangsa tanpa manfaat. Qasim terkejut dengan masyarakat Barat yang pada waktu itu sudah sangat maju dan tidak membeda-bedakan perempuan dengan laki-laki dalam memeroleh kesempatan meraih pendidikan yang baik. ${ }^{15}$ Itulah pemikiran Qasim Amin tentang kebebasan perempuan yang cukup kontroversial pada waktu itu, terutama bagi kalangan ulama al-Azhar. Dia mendapat serangan yang bertubitubi dari para ulama atas ideidenya itu. Namun ia tetap tegar dan terus menyuarakan ideidenya yang menurutnya tidak bertentangan dengan syariah.

Feminisme Model Amina Wadud Muhsin

${ }^{15}$ Qosim, Ibid..,hlm. 147-148.
Amina Wadud Muhsin
adalah pemikir feminis
Muslimah lahir di Malaysia.
Sekarang ia tinggal di Amerika
Serikat dan menjadi guru besar di
Departemen Filsafat dan Studi Agama pada Universitas Commenwelth di Virginia. Salah satu tulisan yang dijadikan sebagai bahan kajian pemikiran feminismenya adalah Qur'an and Woman (1992). Ia pernah membuat geger para ulama dunia, termasuk Syeikh Yusuf alQardawi, ketika ia menjadi khathib dan imam shalat Jum'at di New York City tanggal 18 Maret 2005. Belum lama ini juga terbit buku Amina yang berjudul Inside the Gender Jihad: Women's Reform in Islam (2006). Dalam bukunya Qur'an and Woman, Amina mengawali pembahasannya dengan mengritik penafsiran-penafsiran yang selama ini ada mengenai perempuan dalam Islam. Ia membagi penafsiran tersebut ke dalam tiga kategori, yaitu tradisional, reaktif, dan holistik. Gagasan pertama, mengenai tafsir tradisional. Menurut Amina, harus ada upaya memberikan interpretasiinterpretasi tertentu sesuai dengan minat dan kemampuan mufassirnya yang bersifat 
hukum, tasauf, gramatik, retorik, atau historis. Metodologi yang digunakan bersifat atomistik, yaitu penafsiran dilakukan dengan mengupas ayat per ayat secara berurutan. Tidak ada upaya untuk menempatkan dan mengelompokkan ayat-ayat sejenis ke dalam pokok-pokok bahasan yang tertulis. Yang ditekankan oleh Amina bahwa tafsir-tafsir tradisional itu ditulis oleh kaum laki-laki secara eksklusif. Itulah sebabnya maka hanya laki-laki dan pengalaman laki-laki saja yang direkomendasikan dalam tafsir itu. Sedang perempuan - berikut pengalaman, visi, perspektif, keinginan, atau kebutuhannya ditundukkan pada pandangan laki-laki. ${ }^{16}$

Kategori kedua adalah tafsir yang isinya mengenai reaksi para pemikir modern terhadap sejumlah besar kendala yang dihadapi perempuan yang dianggap berasal dari ajaran alQur'an. Persoalan yang dibahas dan metode yang digunakan seringkali berasal dari gagasan kaum feminis dan rasionalis, namun tanpa dibarengi analisis yang komprehensif terhadap al-

${ }^{16}$ Amina Wadud Muhsin, Qur'an and Woman, ( Kuala Lumpur: Fajar Bakti SDN. BHD. Cet. I. 1993), hlm. 1-2.
Qur'an. Dengan demikian meskipun semangat yang dibawa adalah pembebasan, namun tidak terlihat hubungannya dengan sumber ideologi dan teologi Islam, yaitu al-Qur'an. Kategori ketiga adalah tafsir yang menggunakan seluruh metode penafsiran dan mengaitkan dengan berbagai persoalan sosial, moral, ekonomi, dan politik, termasuk isu tentang perempuan pada era modern ini. Menurut Amina, tafsir model ini merupakan metode terbaik. Dalam kategori inilah Amina menempatkan karyanya. ${ }^{17}$

Metode penafsiran yang digunakan Amina adalah metode yang pernah ditawarkan oleh Fazlur Rahman, yaitu metode neo-modernis. Rahman berpendapat bahwa ayat-ayat alQur'an yang diturunkan dalam waktu tertentu dalam sejarah menggunakan ungkapan yang relatif mengenai situasi yang bersangkutan. Oleh karena itu, pesan al-Qur'an tidak bisa dibatasi oleh situasi historis pada saat ia diwahyukan saja. Misalnya, seorang sahabat yang membaca al-Qur'an harus memahami implikasi-implikasi dari pernyataan-pernyataan alQur'an pada waktu diwahyukan 
untuk menentukan makna yang dikandungnya. Di sisi lain, generasi Islam selanjutnya, yang situasi dan kondisinya berbeda dengan masa Rasulullah, harus tetap membuat aplikasi praktis dari pernyatan-pernyataan alQur'an yang tetap mempertimbangkan makna utama yang dikandungnya. ${ }^{18}$ Dengan argument ini, Amina yakin bahwa dalam usaha memelihara relevansinya dengan kehidupan manusia, al-Qur'an harus terus-menerus ditafsirkan ulang.

\section{Feminisme Model Fatima Mernissi \\ Fatima Mernissi adalah} feminis Muslimah berkebangsaan Maroko. Sekarang ia menduduki jabatan guru besar pada lembaga universiter untuk penelitian ilmiah Universitas Muhammad V Rabat (Maroko). Di antara karyannya adalah Beyond the Veil: Male-Female Dynamics in Modern Muslim Society, (1975) dan The Veil and the Male Elite: A Feminist Interpretation of Women and Islam (1991). Buku lain yang

${ }^{18}$ Aminah.., Ibid,hlm. 4. Dijelaskan juga dalam Fazlur Rahman, Islam and Modernity: Transformation of an Intelectual Tradition ( Chicago: The University of Chicago Press, 1982), hlm. 7. sebenarnya merupakan terjemahan dari buku yang sama adalah Women and Islam: An Historical and Theological Enquiry (1991). Melalui bukunya The Veil and the Male Elite: A Feminist Interpretation of Women's Rights in Islam, Mernissi mencoba mengupas penyebab ketersudutan perempuan sepeninggal Nabi Muhammad Saw. Melalui buku ini pula, Mernissi mengajak umat Islam untuk melakukan peninjauan ulang terhadap hadis-hadis Nabi yang dinilai menyudutkan perempuan pada posisi yang rendah dan hina. Dia melakukan banyak kritik terhadap hadis Nabi yang dinilainya sudah banyak mengalami penyimpangan dan manipulasi.

Menurutnya, penyebab ketersudutan perempuan sepeninggal Nabi Muhammad Saw itu disebabkan, pertam, banyaknya hadis palsu yang bertentangan dengan semangat egalitarianisme yang dibawa Nabi Muhammad SAW. Problem ini muncul setelah Nabi wafat, karena pada saat beliau masih hidup segala persoalan yang dialami kaum Muslim bisa langsung dikonsultasikan dengan beliau. Kedua, munculnya pertikaian di kalangan kaum 
Muslim dalam masalah kepemimpinan (khilafah). Hal ini menjadi pemicu utama ketegangan yang berlarut-larut antara para pemegang otoritas di kalangan kaum Muslim. Mernissi berkesimpulan bahwa suara kalangan elit, baik dari kalangan Anshar maupun Muhajirin lebih mendominasi ${ }^{19}$, sehingga perundingan-perundingan yang terjadi lebih banyak terfokus pada hal-hal yang esensial menurut kalangan elit tersebut. Sangat maklum bahwa setiap kelompok kepentingan yang ada memerlukan pembenaran dari nash suci. ${ }^{20}$ Semangat mencari pembenaran inilah yang menimbulkan dua tendensi yang antagonistic dalam penguraian hadis. Di satu pihak terdapat kecenderungan para politisi lakilaki untuk memanipulasi kesucian hadis, sementara di pihak lain terdapat ulama yang bersikeras menentang para politisi tersebut melalui penguraian fikih, dengan konsepkonsep, kaidah-kaidah dan metode pengujiannya.

${ }^{19}$ Fatima Mernissi, The Veil and the Male Elite: A Feminist Interpretation of Women's Rights in Islam. (New York: Addison Wesley Publishing Company, 1991a), 39.

${ }^{20}$ Mernissi,.. Ibid,hlm. 43.
Ketiga,

Mernissi

menguraikan

hadis-hadis

misoginis yang terus diabaikan.

Salah satu perawi yang mendapat sorotan tajam berkaitan dengan hal ini adalah Abu Hurairah, seorang perawi terkenal dari kalangan sahabat. Secara panjang lebar Mernissi menceritakan latar belakang kehidupan Abu Hurairah yang menyebabkannya antipasti terhadap perempuan. Namun, yang sangat disayangkan Mernissi adalah mengapa alBukhari banyak memasukkan hadis misoginis yang diriwayatkan Abu Hurairah. Mernissi juga menjelaskan kritik Aisyah terhadap Abu Hurairah yang dinilainya dalam meriwayatkan hadis tersebut tidak mendengarkan ucapan Nabi secara lengkap. Hadis ini, Menurut Aisyah, sebenarnya adalah ucapan Nabi yang sedang menggambarkan orang Yahudi mengenai tiga sebab yang menimbulkan bencana, yaitu rumah, perempuan, dan kuda. ${ }^{21}$ Dengan argument berpikir seperti di atas, Mernissi mengajak pembacanya untuk mengkaji kembali persoalan yang berkaitan dengan perempuan, yang selama ini dianggap sudah selesai,

${ }^{21}$ Mernissi, Ibid, 1992, hlm. 73. 
termasuk masalah hijab. Dengan melihat asbāb al-nuzūl ayat hijab, Mernissi menyimpulkan bahwa sebenarnya hijab itu adalah pembatas antara dua laki-laki, yakni Nabi dan Anas Ibn Malik. Dari sini ia kemudian membahas konsep ruang yang diterapkan Nabi. Juga menjelaskan sikap keras 'Umar Ibn al-Khaththab kepada perempuan. Lebih lanjut Mernissi menyoroti kehidupan Nabi bersama isteri-isterinya dan kaum perempuan lainnya. Menurutnya, Nabi bersikap terbuka dan egaliter terhadap kaum perempuan. Yang mengherankan adalah mengapa sikap Nabi yang demikian itu kini terasa asing, bahkan aneh, bagi kebanyakan kaum Muslim setelah beliau wafat. ${ }^{22}$

Sebagai contoh, kasus boleh tidaknya perempuan menduduki jabatan kepala negara, ia menulis sebuah artikel"Can We Women Head a Muslim State". Mernissi mengemukakan perdebatan para ulama mengenai boleh tidaknya perempuan menjadi kepala pemerintahan. Satu pihak dari mereka mengatakan, perempuan boleh saja menjadi kepala negara, karena Islam telah memberi hak yang sama kepada perempuan dan laki-laki. Perempuan

${ }^{22}$ Mernissi, Ibid..,hlm, 192-194. memiliki hak politik yang penuh dan dapat memimpin sebuah negara. Satu pihak yang lain mengatakan, perempuan tidak dapat menduduki jabatan kepala negara, karena ada hadis yang melarang perempuan untuk menduduki jabatan semacam itu. Setelah meneliti alasan-alasan dari kedua belah pihak yang bertentangan di atas, Mernissi melihat bahwa alasan pihak yang membolehkan perempuan menduduki jabatan kepala negara lebih bisa diterima, terutama alasan yang dikemukakan oleh Syeikh Muhammad al-Ghazali, ulama Universitas Azhar Kairo, dalam bukunya al-Sunnat al-Nabawiyyat bain Ahl al-Fighwa Ahl al- $\underline{\text { Hadis. }} .23$

\section{Feminisme Model Asghar Ali Engineer}

Asghar Ali Engineer lahir di Rajasthan (dekat Udaipur, India) tahun 1939. Ia mendapatkan gelar doktor dalam bidang teknik sipil dari Vikram University (Ujjain, India). Pengetahuan agamanya ia peroleh dari ayahnya yang bermazhab Syi'ah.

${ }^{23}$ Muhammad Al-Ghazaliy, Studi Kritis atas Hadis Nabi Saw: Antara Pemahaman Tekstual dan Kontekstual. Alih bahasa: Muhammad Al-Baqirdari Al-Sunnah al-Nabawiyyah baina Ahl al-Fiqhwa Ahl a lHadits. (Bandung: Penerbit Mizan. Cet. V. 1996), hlm, 165. 
Ia seorang aktivis Lembaga Swadaya Masyarakat (LSM/NGO) yang mempunyai perhatian besar terhadap tematema pembebasan dalam alQur'an. Ia menulis artikel berjudul "Toward a Liberation Theology in Islam" yang kemudian diterjemahkan ke dalam bahasa Indonesia "Islam dan Pembebasan" (Yogyakarta: LSIK, 1993). Di antara tulisan yang menyuarakan keadilan dan pembebasan perempuan adalah"The Rights of Women in Islam" (Hak-Hak Perempuan dalam Islam (1994). ${ }^{24} \mathrm{Di}$ awal tulisannya Asghar mengatakan, demi mengekalkan kekuasaan atas perempuan, masyarakat seringkali mengekang normanorma adil dan egaliter yang ada dalam al-Qur'an. Ia juga mengatakan bahwa al-Qur'an merupakan kitab suci pertama yang memberikan martabat kepada kaum perempuan sebagai manusia di saat mereka dilecehkan oleh peradaban besar seperti Bizantium dan Sassanid. Menurutnya, kitab suci ini memberikan banyak hak kepada perempuan dalam masalah

${ }^{24}$ M. AgusNuryanto, Islam, Teologi Pembebasan dan Kesetaraan Gender: Studiatas Pemikiran Asghar Ali Engineer.( Yogyakarta: UII Press. Cet. I. 2001), hlm. 7. perkawinan, perceraian, kekayaan, dan warisan. ${ }^{25}$

Berkaitan dengan perempuan, Asghar menganggap bahwa meskipun al-Qur'an memuliakan perempuan setara dengan laki-laki, namun semangat itu ditundukkan oleh patriarkisme yang telah mendarah daging dalam kehidupan berbagai masyarakat, termasuk kaum Muslim. Meskipun secara normatif dapat diketahui bahwa al-Quran memihak kepada kesetaraan status antara kedua jenis kelamin, secara kontekstual al-Qur'an mengakui adanya kelebihan lakilaki di bidang tertentu dibanding perempuan. Namun, dengan mengabaikan konteksnya, fuqaha berusaha memberikan status lebih unggul bagi lakilaki26. Dalam proses pembentukan syari'ah, ayat-ayat yang berkaitan dengan masalah perempuan sering ditafsirkan sesuai dengan prasangkaprasangka yang diidap oleh banga Arab dan non-Arab praIslam yakni peradaban Hellenisme dan Sassanid-

${ }^{25}$ Nuryanto, Ibid.., hlm. 61.

${ }^{26}$ Engineer, Asghar Ali, Hak-hak Perempuan dalam Islam. Alih bahasa oleh Farid Wajidi dan Cici Farkha Assegaf dari The Rights of Women in Islam. (Yogyakarta: Yayasan Bentang Budaya. Cet. I. 1994), hlm. 56. 
mengenai perempuan ${ }^{27}$. Dengan demikian, interpretasi terhadap ayat-ayat al-Quran sangat tergantung pada sudut pandang dan posisi apriori yang diambil penafsirnya.

Sebagai contoh ayat " alrijaaluqawwamuna 'ala al-nisa' " (QS. al-Nisa' (4): 34) Asghar mengatakan, kata qawwam dalam ayat itu berarti pemberi nafkah dan pengatur urusan keluarga, dan al-Quran tidak mengatakan bahwa laki-laki harus menjadi qawwām. Menurutnya, jika Allah memaksudkan ayat tersebut sebagai sebuah pernyataan normatif, maka pastilah hal itu akan mengikat semua perempuan di semua zaman dalam semua keadaan. Namun, Allah tidak menghendaki hal tersebut ${ }^{28}$. Untuk menguatkannya Asghar mengutip pendapat beberapa pakar seperti Parvez, mufassir alQur'an terkemuka dari Pakistan, Maulana Azad, pelopor hak-hak perempuan, dan Maulana Umar Ahmad Usmani yang pada prinsipnya mengatakan bahwa Allah tidak melebihkan laki-laki atas perempuan. Dari penjelasan di atas, tampaknya Asghar ingin mengatakan bahwa dalam

${ }^{27}$ Ibid.., hlm. 80.

${ }^{28}$ Ibid.., hlm. 63. khazanah tafsir, khususnya yang berkaitan dengan masalah perempuan, sebenarnya ada pendapat-pendapat yang bersikap empati atau properempuan. Meskipun harus diakui, pendapat yang demikian kalah popular dibanding dengan pendapat-pendapat lain yang misoginis. Atas dasar empati inilah, Asghar mencoba menunjukkan alternatif tafsiran atas beberapa ayat al-Qur'an yang selama ini digunakan untuk mengekalkan subordinasi perempuan, yakni berkaitan dengan perceraian, perkawinan, hakwaris, kesaksian, dan hak ekonomis. ${ }^{29}$

\section{Feminisme Model Nasaruddin Umar}

Nasaruddin Umar lahir pada 23 juni 1953 di Ujung Bone, Sulawesi Selatan. Ia salah seorang pengajar fakultas Ushuluddin UIN Syarif Hidayatullah Jakarta. Salah satu karya beliau yang banyak dijadikan referensi dalam kajian gender adalah disertasinya berjudul Perspektif Gender Dalam al-Qur'an. Kemudian di terbitkan menjadi sebuah buku dengan judul"Argumen Gender Perspektif al-Qur'an". Menurut beliau, inti dari ajaran setiap agama -dalam

${ }^{29}$ Ibid.., hlm. 220. 
konteks wilayah Indonesia, khususnya ajaran agama Islam, yakni menganjurkan dan menegaskan pada prinsip keadilan. Al-Qur'an sebagai pedoman moral tentang keadilan, menganjurkan untuk menegakkan keadilan ekonomi, keadilan politik, termasuk keadilan gender. Menurutnya, dalam menanggulangi ketidakadilan diperlukan metode pendekatan penafsiran ayat-ayat al-Qur'an yang bisa dipergunakan untuk memahami ajaran moral agama yang bersifat prinsipil mesti membutuhkan analisis sosial. Pada dasarnya dalam al-Qur'an terdapat ayatayat yang bersifat mutlak dan tidak bisa ditafsirkan lebih dari satu pengertian, yang disebut dalil qoth'iy (dhanniyuldalalah). Ayat-ayat tersebut jumlahnya sangat sedikit, yakni biasanya menyangkut hal-hal yang sangat prinsip. Juga terdapat ayat-ayat yang bias dan boleh menimbulkan tafsiran, yang disebut dalil-dalil dhanny ini lah sesungguhnya untuk memahaminya diperlukan pisau analisis yang harus dipinjam dari ilmu-ilmu lainnya, termasuk meminjam pisau analisis gender. ${ }^{30}$

${ }^{30}$ Mansour Fakih, Analisis..,hlm. 135-
Menurut Nasaruddin alQur'an telah memberikan pandangan optimitis terhadap kedudukan dan keberadaan perempuan. Semua ayat yang membicarakan tentang adam dan pasangannya hawa, sampai keluar dari surga ke bumi, selalu menekan kedua belah pihak dengan kata ganti untuk dua orang (dlamirmutsanna), seperti kata huma, misalnya keduanya mendapat kualitas godaan yang sama dari setan (Qs. Al-A'raf (7): 20), sama-sama memakan buah khuldi dan keduanya menerima akibat terbuang ke bumi (Qs. AlA'raf (7): 22), sama-sama memohon ampun dan samasama diampuni Allah (Qs. AlA'raf (7):23). Setelah di bumi, antara satu dengan yang lainnya saling melengkapi, mereka adalah pakaian bagimu dan kamu juga adalah pakaian bagi mereka (Qs. Al-Baqarah (2): 187).

Secara ontologism dapat dikatakan bahwa, masalahmasalah subtansial manusia tidak diuraikan panjang lebar di dalam al-Qur'an. Yang ditekankan dalam al-Qur'an berupa eksistensi manusia sebagai hamba (Qs. al-Dzariyat: 56) dan sebagai wakil Allah di bumi (Qs. al-An'am: 165). Manusia adalah 
satu-satunya makhluk eksistensialis, karena hanya mahluk yang namanya manusia yang bisa turun naik derajatnya di sisi Allah. Menurutnya, ukuran kemuliaan di sisi Allah adalah prestasi dan kualitas tanpa membedakan etnik dan jenis kelamin sebagaimana tertera dalam al-Qur'an surat al-Hujarat: 13. Dalam al-Qur'an juga tidak menganut faham the second sex yang memberikan keutamaan kepada jenis kelamin tertentu, atau the first etnic, yang mengistimewakan suku tertentu. Laki-laki dan perempuan mempunyai potensi yang sama untuk menjadi khalifah/pemimpin (Qs. anNisa':124 dan Qs. an-Nahl: 97). ${ }^{31}$

Hampir semua tafsir yang ada mengalami bias gender disebabkan karena pengaruh budaya Timur-Tengah yang Androcentris. Sebagai salah satu contoh, kata al-Rijal bentuk jamak dari al-rajul, yang akar katanya huruf ra', jim, dan lam. Kata ini membentuk derivasi beberapa kata seperti rajala (mengikat), rajila (berjalan kaki), al-rijl (telapak kaki), al-rijlah (tumbuhtumbuhan), dan al-rajul (berartilaki-laki). Misalnya dalam Islam, VOL.I, 1 Juli-Desember 1998.

Firman

Allah: wastasyhidusyahidaini min rijalikum.32(Qs. al-Baqarah: 282). Dalam kasus tertentu, misalnya proses reproduksi, tidak ditemukan perbedaan secara khusus anatara laki-laki dan perempuan. Sedikit pun tidak ditemukan perbedaan antara laki-laki dan perempuan dalam proses dan mekanisme secara biologis. Peroses dan mekanisme biologis tidak bisa dijadikan alasan untuk memojokan atau mengistimewakan salah-satu di antara kedua jenis kelamin. ${ }^{33}$

Dalam hal pembagian kerja, Nasaruddin berpendapat bahwa perempuan dalam ranah domestik dan laki-laki dalam ranah publik. Banyak orang menganggap bahwa hal ini merupakan sesuatu yang alamiah, dan diterima begitu saja tanpa ada komentar apapun. Relasi kuasa dan status yang berbeda antara laki-laki dan perempuan menjadi dasar pula dalam pembagian kerja. Semisal dalam masyarakat tradisional dikenal pembagian kerja secara seksual, laki-laki sebagai

32 "Dan persaksikanlah dengan dua orang saksilaki-laki di antar kamu.(Qs. alBaqarah: 282).

${ }^{33}$ Nasruddin Umar, Argumen Kesetaraan Gender Perspektif Al-Qur'an, (Jakarta:Dian Rakyat, 2010), hlm. 200-202. 
pemburu dan perempuan sebagai pengasuh, maka hal yang sama masih juga dijumpai dalam masyarakat modern. Dalam dunia bisnis, perempuan diarahkan sebagai sekertaris dan laki-laki pemimpin. Dan dalam rumah tangga urusan produktif seolah-olah menjadi tugas lakilaki sementara urusan reproduksi dan ke rumah-tanggaan tugas perempuan. ${ }^{34}$

Secara historis, setiap kelompok masyarakat mempunyai konsepsi-konsepsi ideologis tentang jenis kelamin. Hampir semua kelompok masyarakat menggunakan jenis kelamin sebagai kriteria penting dalam pembagian kerja. Pekerjaan yang diperuntukkan kepada laki-laki biasanya dianggap sesuai dengan kapasitas biologis, psikologis, dan sosial sebagai laki-laki yang dikonsepsikan orang yang memiliki otot lebih kuat, tingkat resiko dan bahayanya lebih tinggi karena bekerja di luar rumah. Sementara perempuan kapasitas biologisnya dikonsepsikan sebagai orang yang lemah dengan tingkat resiko lebih rendah, cenderung bersifat 52. mengulang, tidak memerlukan konsentrasi yang intensif. Karena itu tingkat keterampilan perempuan diangap rata-rata lebih rendah dibanding laki-laki. Karena itu, Nasaruddin memahami gender sebuah ideide kutural yang menentukan harapan-harapan kepada laki-laki dan perempuan dalam berinteraksi dan berkomunikasi antara satu dengan lainnya dalam masyarakat. Dalam perspektif budaya, laki-laki dikategori sebagai maskulin dan feminine dikategorikan perempuan. Secara umum, maskulin diartikan sebagai sesuatu yang memiliki sifat-sifat kejantanan, baik berupa kepribadian, perilaku, pekerjaan. Sebaliknya, feminism diartikan sebagai sesuatu yang memiliki sifat-sifat keperempuan, misalnya lembut, perasa, mudah menangis, irasional. Perempuan tetap memiliki keinginan untuk bergerak secara leluasa guna meningkatkan status dan rasa percaya diri, tetapi budaya sosial membatasi keinginan mereka, terutama bagi mereka yang telah berumah tangga dan mempunyai anak. Pada saat ini perempuan menghadapi beban ganda. Dari satu segi mereka perlu berusaha sendiri, tetapi lain pihak harus 
lebih konsisten mengasuh anak dan mengasuh keluarga. 35

\section{Kesimpulan}

Penelitian literatur dengan menggunakan

pendekatan feminisme yang digagas oleh para tokoh dalam mengkaji Islam kontemporer dilakukan dalam rangka; pertama, sebagai upaya melahirkan model bacaan baru terhadap pemahaman keagamaan dalam kontek kontemporer yang berorietasi pada pembebasan perempuan dari belenggu-belenggu tradisi yang menjerat. Proses-proses kesetaraan (dalam arti hukum Islam) dalam presfektif ini diharapkan dapat menghasilkan produk hukum di mana manusia sebagagai subjek hukum ditempatkan pada posisi yang tidak saling mensubordinasi, mendiskriminasi atau memarginalkan satu atas yang lain atas dasar apapun, baik etnisitas, gender, agama, maupun ras.

Kedua, teori dan gagasan yang dibangun oleh para tokoh feminis Islam justru melegitimasi eksistensi keberadaan wanita. Kaum wanita diberikan porsi hak, kewajiban serta hukum yang

${ }^{35}$ Ibid., hlm.65-67. sama dengan laki-laki. Dalam salah satu ayat, Tuhan menyampaikan pesan bahwa ganjaran kebaikan yang diterima wanita sama persis dengan ganjaran yang laki-laki terima dalam mengamalkan kebaikan. Islam memberikan ruang lingkungan dan sosial yang layak bagi perempuan. Tidak seperti kebudayaan elite Yunani yang mengharuskan wanita selalu berada di dalam istana. Islam memberikan ruang bagi wanita untuk keluar dan berinteraksi. Namun dengan beberapa catatan yang memang harus dipertimbangkan demi kemaslahatan bersama. Wanita juga mendapatkan kebebasan untuk ikut andil dalam menjalankan perputaran roda ekonomi. Mereka memiliki hak untuk mengatur perdagangan serta berpartisipasi dalam ruang publik.

Ketiga, setiap melakukan penelitian selalu ada kelemahan dan kelebihan, baik dari segi teori, metode, analisis data maupun pendekatan penelitian. Penelitian literatur biasanya kaya akan teori namun kesulitan pada tataran praktis. Sebagaimana ditemukan dalam penelitian ini, penulis kesulitan dalam menerapkan teori feminis siapa 
yang dianggap sesuai dengan kontek kontemporer ini. Namun begitu, tetap berharap teori-teori feminis yang telah digagas oleh para tokoh di atas menjadi literasi bagi peneliti berikutnya.

\section{Daftar Pustaka}

Al- Qur'an dan tarjamah.

Ahmad, Leila, Women and Gender in Islam: (New Haven and Landon: Yale

University Press, 1982).

Al-Ghazali,Muhammad, Studi

Kritisatas Hadis Nabi Saw: Antara Pemahaman

Tekstual dan Kontekstual. Terj. oleh Muhammad AlBaqir"Al-Sunnah alNabawiyyah baina Ahl alFiqhwaAhl a 1-Hadits". (Bandung: Penerbit Mizan. Cet. V. 1996).

Amin,Qosim, Sejarah

Penindasan Perempuan:

Menggugat Islam

Laki-laki, Menggurat

Perempuan Baru.Terj. Syariful Alam dari The New Woman: A Document in the Early Debate of Egyptian Feminism. (Yogyakarta: Ircisod. Cet. I, 2003).
Asghar, Ali,Engineer, Hak-hak

Perempuan dalam Islam.Terj. oleh Farid

Wajidi dan Cici Farkha Assegafdari The Rights of Women in Islam. (Yogyakarta: Yayasan Bentang Budaya. Cet. I. 1994).

Carr,Anne, Tranforming Grace:

Christian Tradition and Women's Experience (San Francisco: Harper \& Row, 1988).

Connolly, Peter, (ed.), Aneka Pendekatan Studi Agama, (Yogyakarta: LKiS, Cet, III2011).

El-Sadawi,Nawal,The Hidden Face of Eva: Women in the Arab World. (Boston: Beacon Press, 1981).

Fakih, Mansour, Analisis Gender ETransformasi Sosial, (Pustaka Pelajar, Yogyakarta, 2012).

Gery,Mary, Redeeming the Dreem: Feminism, Redemption and Christian Tradition. SPCK, 1989 dan Judith Plaskow, Sex, Sin, and Grace: Women's Experience and the 
Theologies of Reinhold Niebuhr and Paul Tillich. (Washington: University Press of America, 1980).

Gross, Fatima, Hindu Female

Deities as a resource for the contemporary rediscovery of the goddess, Journal of American Academy of Religion, 1974).

Hyman, Paula, “The Jewish

Family: looking for a usable past" dalam Susannah Heschel (ed.). On Being A Jewish Feminist: A Reader. (New York: Schocken Books, 1983).

Andrews, William, (ed.). Sisters of the Spirit: Three Black Women's Autobiographies of the Ninteenth Century. (Bloomington: Indiana University Press, 1986).

J. Brooten,Bernadette, Women

Leaders in the Ancient Synagogue: Incrption

Evidence and Background Issue. (Chicago: Scholar Press, 1982).

Masrur, Muhammad,Shodiq, dalamhttps://www.nu.or.i d/post $/ \mathrm{read} / 79772 /$ femini sme-dalam-islam, 2017.

Mernissi, Fatima, The Veil and the Male Elite: A Feminist Interpretation of Women'sRights in Islam. (New York: Addison Wesley Publishing Company, 1991a).

Muhsin, Amina Wadud,Qur'an and Woman, ( Kuala Lumpur: FajarBakti SDN. BHD. Cet. I. 1993).

Nasution, Harun, Pembaharuan dalam Islam: Sejarah, Pemikiran, dan Gerakan, (Jakarta: Bulan Bintang, 1991, Cet. VIII).

Nuryanto, M. Agus,Islam, Teologi Pembebasan dan Kesetaraan Gender: Studi atas Pemikiran Asghar Ali Engineer.( Yogyakarta: UII Press. Cet. I. 2001).

O'Brien,Susan, “ Terra Incognita: The Nun in nineteenthcentury England", Past and Present 121, 1988).

Paramadina, JurnalPemikiran Islam, VOL. I, 1 JuliDesember 1998. 
Qutub,Muhammad, Qadliyyah Tahrir alMar'ah.Terj. Tajudin "Setetes Parfum Wanita" (Jakarta: Pustaka Firdaus, 1993).

Radford,Rosemary,Ruetherartikel nya, "Feminism and Patriarchal religion: principles of ideological critique of Bible" Journal for the Study of the Old Testament, 22, 1982). Dan "Feminist Interpretation: A method of correlation" dalam Russell, Feminist Interpretation of the Bible.

Rahman, Fazlur, Islam and Modernity: Transformation of an Intelectual Tradition
(Chicago: The University of Chicago Press, 1982).

Sukri, Suhandjati, Sri, (Ed.). Bias Jender dalam Pemahaman Islam, (Yogyakarta: Gama Media. Cet. I. 2002).

Trible, Phyllis, Eve and Adam:

Genesis 2-3 reread, dalam Christ dan Plaskow, Womanspirit Rising, dan Judith Plaskow, The Coming of Lilith.

Umar, Nasaruddin,Argumen Kesetaraan Gender Prespektif Al-Qur'an, (Jakarta: Dian Rakyat, Jakarta, 2010). 